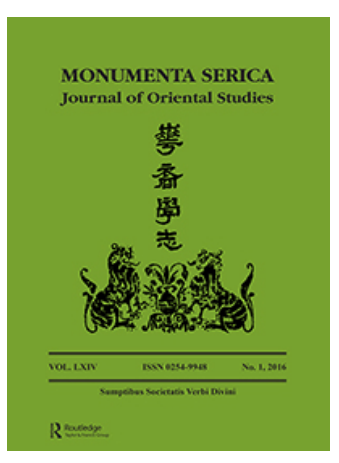

Monumenta Serica

Journal of Oriental Studies

ISSN: 0254-9948 (Print) 2057-1690 (Online) Journal homepage: http://www.tandfonline.com/loi/ymon20

\title{
The Gradual Growth of the Mohist Core Philosophy
}

\section{Carine Defoort}

To cite this article: Carine Defoort (2016) The Gradual Growth of the Mohist Core Philosophy, Monumenta Serica, 64:1, 1-22

To link to this article: http://dx.doi.org/10.1080/02549948.2016.1169755

曲 Published online: 20 May 2016.

Submit your article to this journal

Q View related articles $₫$

View Crossmark data $₫$ 


\title{
THE GRADUAL GROWTH OF THE MOHIST CORE PHILOSOPHY
}

\author{
Tracing Fixed Formulations in the Mozi*
}

\section{CARine Defoort}

Because of the paucity of hard facts in our knowledge of early texts such as the Mozi, we inevitably have had to rely on assumptions when interpreting these texts. These assumptions have contributed to the portrayal of Mo Di as a philosopher, the founder of Mohist thought, and promoter of a coherent thought system in Ten Core Ideas. We can read the Mozi in a novel way by methodologically putting these assumptions on hold, not necessarily by rejecting them. This approach draws attention to the differences among the Ten Core Ideas, their not quite fixed forms, and their remarkably poor presence in the Mozi. It leads to another, equally plausible portrayal of Mohist thought as gradually shaped by its authors and editors along with the formation of the book.

KeYwords: Mozi, Ten core ideas, Early Chinese texts, Qing emendations

Some academic debates about Mohism concern historical topics as, for instance, the dates and provenance of its original founder, Mo Di 墨翟 (e.g. Guo Chengzhi I 990, I992; Zhang Zihan I99I; Zheng Qiangsheng I998); ${ }^{\mathrm{I}}$ others discuss an aspect of its philosophy, such as Mozi’s 墨子 supposed utilitarianism (e.g. Ahern I976; Taylor I979; Brandt I989; Hansen I989; Vorenkamp I992; Soles I999). Such historical and philosophical discussions often share the common narrative of Mo Di as a philosopher, the founder of Mohist thought, and inventor of a set of Ten Core Ideas, including "care for all," "moderate expenses," "the will of Heaven," etc. This article does not deny the value of this shared narrative, but argues that, as a dominant portrayal, it has highlighted some interpretations of the text while consistently obscuring other equally plausible readings. The alternative that this article suggests is that the full set of ten fixed formulations may not have originated from one founding figure, and that perhaps not even each of the ten doctrines as we know them today originated directly from him. Some of them may originally have been presented only in inchoate form. Without explicitly stating them, Mozi may have

* I thank Nicolas Standaert, Lee Ting-mien, the anonymous reviewers of Monumenta Serica, and the participants of the two conferences where an earlier draft of this article was presented, especially Bryan van Norden, Eirik Lang Harris, and P.J. Ivanhoe: "Traditional Non-Confucian Perspectives on Social and Political Organization and Order" (Hong Kong, March 20I4) and "Reading the 'Masters': Contexts, Textual Structures, and Hermeneutic Strategies” (Brno, September 20I4).

I Ren Jiyu's dating of Mozi "ca. 480-390" has been accepted at the Mozi Research Institute in Tengzhou 滕州. A major part of their museum is dedicated to the question of Mozi's dates and provenance: Tengzhou (Shandong) versus Luyang 魯陽 (Henan). 
said things that inspired later authors to formulate the tenfold Mohist core philosophy.

My attempt to present such an alternative reading follows an earlier discovery, namely that the way Mozi is generally presented today only came into existence in the last centuries. The nowadays current portrayal of Mozi as the inventor of a systematic set of Ten Core Ideas is thus largely a modern phenomenon. Only around the I9th century did scholars begin to identify Mozi's thought with exactly ten ideas coinciding with the titles of the Core Chapters (chs. 8-37) and with one string of mottos from a Dialogue Chapter (ch. 49). The most dominant portrayal during the almost 20 preceding centuries was that of Mo Di as a heretic master threatening the $r u$ 儒 way of life (Defoort 20I 5 ).

Like some other less dominant portrayals of Mozi, these two - the philosopher and the heretic - have inevitably relied on assumptions. The philosophical portrayal consists of such building blocks as a "founder" of a "school," preaching a "philosophy," and being represented in a "book" or parts thereof. Such assumptions have been necessary to supplement our striking lack of firm knowledge concerning the exact nature of the Mozi and its contributors before the Han dynasty. Neither Sima Qian 司馬遷 (ca. I45-86 BCE) ${ }^{2}$ nor Liu Xiang 劉向 $\left(79-8\right.$ BCE), ${ }^{3}$ nor any other early author provided posterity with much information on the Mozi's structure, length, chapter titles, authors, and even its existence. ${ }^{4}$ Informed by recent archeological research and putting on hold some building blocks of the current portrayal, this article investigates the possibility that a proto-Mozi may have evolved through stages of textual fluidity and instability. ${ }^{5}$ This approach does not assume a full-blown philosophy in the mind of the founder of Mohism, but traces a slowly emerging set of ideas along with the gradual creation of the book. This sheds light on otherwise seldom noticed data such as the differences between the Ten Core Ideas, their remarkably poor presence in the book, their gradual fixation, and the forgotten textual emendations made by Qing scholars.

\section{LOCATIONS OF FIXED EXPRESSIONS}

The starting-point of this research are the expressions that at some point - before or in the Han dynasty - have come to function as titles of the Core Chapters, and that are generally considered representative of early Mohism: shang xian 尚賢 (elevate the worthy), shang tong 尚/上同 (conform upward), jian ai 兼愛 (care for all), fei gong 非攻 (against military aggression), jie yong 節用 (moderate expenses), jie zang 節葬 (moderate burials), tian zhi 天志 (the will of Heaven), ming gui 明鬼

${ }^{2}$ There is nothing at all in the Shiji on the book Mozi. On the person Mo Di it has: "Probably Mo Di was a minister in Song, he was good at defense and practiced 'moderating expenses'. Some say he lived in the same time as Kongzi; others say he was later.” 蓋墨翟, 宋之大夫, 善守禦, 為 節用。或曰並孔子時, 或曰在其後 (Shiji 74:2350).

3 There is one line in Shiji suoyin 史記索隱 (8th c.) commenting on Shiji 74:2350 that possibly quotes Liu Xiang but it does not contain information on the book Mozi. See below.

${ }^{4}$ The earliest information on the Mozi is Hanshu 漢書 30:1738. See below. There is more (not necessarily historical) information on the person Mozi than on the book named after him. Stories about the figure Mo Di occur in the Mozi and in other sources.

5 Awareness of the complexity of the Mozi (and of other early Chinese books) was inspired by Maeder I 992 and by Japanese scholarship as presented by Hashimoti 20 Iо. 
(insight in the existence of ghosts), fei yue 非樂 (against music), and fei ming 非命 (against a belief in fate). Searching these expressions throughout the book, I distinguish between the earliest existing received version of the Mozi, namely the Daozang edition published in I447, and modern emendations from the late Qing onward. ${ }^{6}$ The questions I ask are: When do the authors explicitly adopt and defend (or attribute and reject) specific ideas or policies? How do they label them? Are these labels fixed? And how are they presented in the text?

My focus on the exact formulation of specific expressions is inspired by Michael Schoenhals' study of “fixed formulations” ( $t$ ifa 提法) in contemporary Chinese politics, which have a fixed form, are omnipresent in political discourse, meant to promote a policy or reject impediments to it, are considered socially and politically effective, and treated as political or ideological entities. ${ }^{7}$ I suggest that the Mozi attests to the emergence of similar fixed expressions or formulations in the Warring States intellectual scene, when its authors began to associate themselves with a set of short phrases, mottos, clichés, labels, slogans, or watchwords - in short "fixed formulations" - and attributed some to their proclaimed opponents. I search the Core Chapters (chs. 8-37, also named "triplets" or "triads"), Dialogues (chs. 46-50), and the Opening Chapters (chs. I-7) for expressions with a fixed form of two characters that are used repetitively, treated as doctrines or teachings, advocated or condemned, and considered influential on social order. ${ }^{8}$ There are three textual locations where fixed formulations can be found in the early Chinese corpus: chapter titles, single labels, and strings.

\section{Titles}

The most obvious location of fixed formulations might seem to be chapter titles. By their very nature, titles formally set an expression aside as an entity. But only some of them represent the chapter's content, in which case these expressions might also occur in the chapter's body. The Inner Chapters of the Zhuangzi 莊子 and the Core Chapters of the Mozi have such titles. The recent excavation of various types of manuscripts has further illustrated the complex and unsettled nature of chapter titles in the Warring States period. Following up the research of scholars such as Yu Jiaxi 余嘉锡 and Li Ling 李零, the Taiwanese researcher Lin Qingyuan distinguishes between different types of manuscripts: those on thought (sixiang 思想), history, techniques, medicine, law, poetry, etc. He argues that the habit to create content titles for texts about thought began to occur, but only occasionally, in the mid-Warring States period. In other words, such texts often carried no titles. ${ }^{9}$ It is unclear at which stage of the Mozi's formation the Core Chapters titles were

6 The Daozang edition was completed in I 445 and printed in I447. See Schipper - Verellen 2004, p. 2.

7 Schoenhals I992, pp. 6-29.

8 Other parts of the Mozi, namely the Dialectical (chs. 40-45) and Defense (chs. 52-7I) Chapters are not only more technical in content but also textually more corrupt. In a less fixed formulation, mottos sometimes have three characters. Longer slogans, such as "jian xiang ai jiao xiang li" 兼相愛交相利 (inclusively care for each other and mutually benefit each other) are not included in this study.

9 Lin Qingyuan 2004, pp. 7-8, 48-50, 67-68. 
created - before, during or after the final edition. A close reading may provide some indications of the authors' own awareness of the titles (see part 2).

\section{Single Labels}

Bypassing the titles and moving to the body of the text, we can sometimes identify fixed formulations in a context of political debate, as is the case in the Mozi. I tentatively identify expressions as "fixed formulations" when they are often repeated, advocated as a core policy, explicitly endorsed or attributed to somebody, named a doctrine/statement (yan 言), proposal/explanation (shuo 說), Way (dao 道), policy/government (zheng 政), law/model ( $f a$ 法) or teaching (jiao 教), to which one holds on ( $z h i$ 執), which one acclaims ( $s h i$ 是) or condemns ( $f e i$ 非), and which is said to be supported by ancient writings (shu 書, wen 文) or by their exemplary protagonists (Yao 堯, Shun 舜, Yu 禹, Tang 湯, Wen 文, Wu 武). No other early Chinese source contains more such claims than the Mozi (see part 3).

\section{Strings}

A third textual location of short formulations are strings of views attributed to one master, e.g. stating that he promoted the policies AB and XY. Some Warring States and Han chapters combine such strings in lists of various masters. ${ }^{\text {IO }}$ The "Tianxia" 天下 (The world) chapter of the Zhuangzi, for instance, characterizes different masters with more or less fixed formulations. It describes Mo Di and his disciple Qin Guli 禽滑嶅 as follows:

They originated "against music" and named it "moderate expenses." When alive they did not sing, and for the dead they did not wear mourning. Mozi "cared for everyone," "benefited everyone," and was "against fighting." His way was not to get angry. ${ }^{\text {I }}$

The identification of five fixed formulations in this string - "against music" fei yue 非 樂, “moderate expenses” jie yong 節用, “cared for all” fan ai 泛愛, “benefited all” jian $l i$ 兼利, and “against fighting” fei dou 非鬥 - is tentative. The formulations consist of two characters; even though they do not recur repetitively in this Zhuangzi chapter, we do recognize them as more or less exact echoes of formulations in their original habitat, namely the Mozi. ${ }^{\mathrm{I} 2}$ The policies in this string are lifted out of their original context and presented here in a rather tolerant overview of various masters filling the intellectual scene. The Mozi contains some strings of its own policies advocated

ro Other well-known examples of chapters containing such lists of strings are Xunzi 荀子 “Fei shi'er zi” 非十二子, Shiji 史記 “Taishigong zixu” 太史公自序 and the bibliographical treatises that followed in their track. See Csikszentmihalyi - Nylan 2003, pp. 62-64.

II 作為非樂, 命之曰節用。生不歌, 死無服。墨子泛愛兼利而非鬥。其道不怒. Zhuangzi 33:98/7. Except when specific fragments are commonly recognized by a number (e.g. Lunyu,1.2; Laozi, 24; Lüshi chunqiu I7/7.I; or Mengzi 3 A9), all quotes of Chinese masters refer to the Chinese Ancient Text Centre's indexes edited by D.C. Lau (see Lau I995-): the chapter number is given first, followed by a colon and then the page number and line number separated by a slash.

${ }^{\mathrm{I}} 2$ The first two (fei yue, jie yong) are part of the well-known set of ten core theses; the last three ( fan ai, jian li, fei dou) are less fixed but generally identified with early Mohist core ideas. Perhaps "not to get angry" (bu nu 不怒) could count as a sixth one. 
in relatively fixed formulations, but it does not yet put its own teacher in lists along with various masters, as in the last Zhuangzi chapter (see part 4 ). ${ }^{\mathrm{I}}$

\section{The Ten Core Ideas}

Before turning to chapter titles, single attributions, and strings, let us take a closer look at the occurrence of the ten expressions throughout the Mozi, based on their formulation as Core Chapter titles. How often, excluding the titles themselves, does each expression occur in the triplet named after it? And how often in the rest of the book, including the other triplets?

A quick look at Table I provides us with the following information: First, the expressions are remarkably absent from their own triplets except the first two, "Shang xian" and "Shang tong." In other words, the authors of most Core Chapters - "Jian ai," "Fei gong," "Jie yong," "Jie zang," "Tian zhi," "Ming gui," "Fei yue," and "Fei ming" - almost never literally refer to the expression of their own current title. Second, in the rest of the book, the fixed formulations are even less present, including those of the first two triplets, "Shang xian" and "Shang tong." And third, there is a relatively high number of editorial restorations by Qing scholars involved in the fixed formulations. All this does not prove, of course, that the ten theses were unknown or unimportant for the original authors of the Mozi, nor does it make a coherent philosophical reconstruction of the Ten Core Ideas unwarranted. But this type of information, that only becomes visible when the more current assumptions are temporarily put on hold, may contribute to an alternative portrayal of the Mozi.

TABLE I

\section{OCCURRENCE OF THE TEN FORMULATIONS OF THE CORE CHAPTER TITLES IN THE} DAOZANG EDITION OF THE MOZI (EXCLUDING THE TITLES THEMSELVES)

\begin{tabular}{|c|c|c|c|c|}
\hline \multirow{2}{*}{$\begin{array}{l}\text { Formulation of the Core } \\
\text { Chapter titles } \\
\text { shang xian 尚賢 }\end{array}$} & \multicolumn{3}{|c|}{$\begin{array}{l}\text { Occurrence in the triplet 上中下 } \\
\text { named after the core idea }\end{array}$} & \multirow{2}{*}{$\begin{array}{l}\text { Occurrence in the rest of the } \\
\text { book, including the other } \\
\text { triplets } \\
\text { I }\end{array}$} \\
\hline & 4 & I 5 & I3 & \\
\hline shang tong 尚/上同 & 6 & I $5[\mathrm{I}]$ & I 5 & $2[\mathrm{I}]$ \\
\hline jian $a i$ 兼愛 & ○ & ० & I & $9[\mathrm{I}]$ \\
\hline fei gong 非攻 & ○ & ० & I & {$[\mathrm{I}]$} \\
\hline jie yong 節用 & ○ & I & /// & $\mathrm{I}[\mathrm{I}]$ \\
\hline jie zang 節葬 & /II & /// & [I節喪] & 2 \\
\hline tian zhi 天志 & I & ० & $\begin{array}{l}\text { I [3天之] } \\
\text { [3 天之志] }\end{array}$ & o [ 2 天之志] \\
\hline ming gui 明鬼 & /// & /// & ० & $\circ$ \\
\hline fei yue 非樂 & I & /// & /// & I \\
\hline fei ming 非命 & ० & ० & O & 3 \\
\hline
\end{tabular}

Not transmitted chapters are indicated with //I. Square brackets indicate variants and editorial emendations made by Qing scholars.

${ }^{13}$ Such syncretic lists of several masters seem to postdate the Mozi's Core Chapters and probably began with the Qin dynasty. See e.g. Lüshi chunqiu 呂氏春秋 I7/7.I and Shizi 尸子, “Guang (ze)”廣(澤): part I, IO:IO/4. 


\section{TITLES OF CHAPTERS}

The most obvious location of fixed expressions are content titles of writings concerning thought, as is the case with the Core Chapters. The study of excavated texts has shown that, from the mid-Warring States period onward, writings about thought occasionally carried such titles. Considering the absence of information about the Mozi's structure and chapter titles before the Han dynasty, we cannot determine with certainty when the Core Chapters were structured and titled the way that Ban $\mathrm{Gu}$ 班固 (32-92) found them when he recorded a Mozi in $7 \mathrm{I}$ pian. ${ }^{\mathrm{I} 4}$ There seems to be a consensus among Mozi scholars that Liu Xiang had a hand in editing the Mozi. ${ }^{15}$ Even if this was the case, we still do not know how much of the Mozi had been edited when he started working on it: Were the Core Chapters structured as they are now? Did they have titles? And if so, since when? In sum, these titles may have existed in the Warring States period from the very outset of the Mozi's creation, but they may also have been added before, by, or even after Liu Xiang.

Is there anything that we can, however tentatively, deduce from the received text concerning the status and timing of the Core Chapters titles? Imagine that you lived in the mid-I9th century and hence had never heard of "the ten Mohist theses"; you were invited to read the Core Chapters without seeing the titles and you were asked, on the basis of the text alone, to reconstruct titles representing the content. Which titles would you come up with? Would they coincide with the current titles? Does the title fit the content? And does the content, moreover, suggest that its title already preceded the text as a fixed formulation for a specific doctrine or policy? Or does the idea of the title merely occur in a less fixed form throughout the text? Is there a reason why the expression of the title does not or hardly occur in the chapter? Is it treated as crucial to the argument - that is: often repeated, introduced at the beginning, and stressed in the conclusion? All in all: Do we have the impression that (some of) the authors may have been aware of the title under which heading their thoughts have been collected and transmitted? I roughly

I4 The last Mohist book mentioned in Hanshu, "Yiwenzhi” 藝文志 (Treatise on Arts and Literature) is Mozi in 7I pian (墨子七十一篇), which might indicate that the I 8 lost chapters were still extant in the Han. See Knoblock - Riegel 2013, p. I 5. In what seems a summary of the Shiji record, Ban Gu adds some information on the person Mozi: "His name was Di, he was a minister in Song, and lived after Kongzi” (名翟, 為宋之大夫, 在孔子後). And finally, in a brief evaluation of the Mohist lineage, he provides us with the longest extant string in the early period (except for one in the Mozi) of relatively fixed formulations - gui jian 貴儉 (valuing frugality), jian ai 兼愛 (care for all), shang xian 上賢 (elevating the worthy), you gui 右鬼 (supporting ghosts), fei ming 非命 (against belief in fate), and shang tong 上同 (conforming upward) (Hanshu 30:1738). See Defoort 20I4.

I5 Sun 20I I, p. 655; Knoblock - Riegel 20I3, pp. I4-I 5. They refer to Ban Gu's comment on the deletion of duplicates from the Mozi among the military chapters (Hanshu 30:I762). Ban used Liu Xin's 劉歆 (46 BCE - 23 CE) Qilüe 七略 (Seven Summaries), which was based on the Bielu 別錄 (Separate Records) that gathered the records of Liu Xiang (79-6 BCE) presented to court after 26 BCE. There is, moreover, one line in Shiji suoyin (early eighth century) quoting the Bielu about the Mozi: "As to the book Mozi, there was a Wenzi who was the disciple of Zixia. He asks questions to Mozi" (Shiji 74:2350). These two comments are the only testimony of what may have been Liu Xiang's contribution to the edition of the book Mozi. 
distinguish between three categories - perfect, relatively good, and relatively poor matches - and illustrate each with the most representative triplet.

\section{A Perfect Match between Core Chapters and Their Titles}

As was clear from Table I, the two first triplets, "Shang xian" (chs. 8, 9, Io) and "Shang tong" (chs. II, I2, I3) seem to be aware of the presence and importance of their title. It is therefore very probable that the authors consciously wrote a chapter to promote the policy of which an already existing fixed formulation functioned as title.

TABLE 2

OCCURRENCE OF THE TITLE'S EXPRESSION IN THE TEXT OF TWO TRIPLETS WITH A PERFECT MATCH BETWEEN THEIR CONTENT AND TITLES IN THE DAOZANG EDITION

\begin{tabular}{llll}
\hline & 上 & 中 & 下 \\
\hline 尚賢 & 4 & I 5 & I3 \\
尚同 & I [5 上同 & I3 [I] [2 上同] & I4 [I 上同] \\
\hline
\end{tabular}

Like the second triplet, ${ }^{\mathrm{I}}$ the "Elevate the Worthy" chapters contain a wellstructured and powerful promotion of the main idea, especially ch. 9, "Shang xian, zhong". ${ }^{\mathrm{I} 7}$ As Table 2 shows, the expression shang xian occurs fifteen times in the chapter, which begins by stressing the importance of "elevating the worthy" for the state's wellbeing.

Our Master Mozi said: When the kings, dukes, and great men of today lord over men and people, preside over their altars of soil and grain, and govern their states, they desire prolonged protection and avoidance of failure. Why then do they not examine how "elevating the worthy" is to form the foundation of their government? ${ }^{\text {18 }}$

Like in a catechism, the argument is laid out for everyone to understand and easily remember:

How do we know that "elevating the worthy" is to form the foundation of government? I say: From the fact that there is order whenever the noble and wise govern

I6 The "Shang xian" triplet is more straightforward since the title "Shang tong" (Conform upward) is somewhat ambiguous. Some scholars do not translate shang tong 尚同 as an adverb-verb construction but as a verb-object construction ("exalt unity/conformity"). See Johnston 20I0, p. xxxix; Knoblock - Riegel 20I3, p. 30. These translations are indeed possible, but the adverb-verb construction occurs more often in the triplet.

${ }^{17}$ Watanabe Takashi considers this chapter the youngest of the three and he dates it to ca. 220 BCE. See Watanabe 1977, p. 4. For a variety of views on the dates of the Mozi chapters, see also Defoort - Standaert 2013, pp. 4-I9.

I8 子墨子言曰: 「今王公大人之君人民, 主社稷, 治國家, 欲脩保而勿失。故 [replaced by 胡 as it is in similar fragments] 不察尚賢為政之本也. 9:IO/I7-I8. 
the stupid and base; and from the fact that there is chaos whenever the stupid and base govern the noble and wise. That is how we know that "elevating the worthy" is to form the foundation of government. ${ }^{\text {I9 }}$

Then follows the example of the sage-kings who did exactly this, and the counterexample of "the kings, dukes, and great men of today" (今王公大人) failing to adequately emulate these models in the government of their states, even though in private matters they know well enough how to select and award the most capable workers. Next, the authority of ancient documents is adduced with quotes explaining that the sage-kings did not fail in using the "elevation of the worthy" and "employment of the capable" to conduct government.

Therefore the sage-kings in antiquity were simply able to examine how to conduct government by "elevating the worthy" and "employing the capable." 20

The authors go on pointing out that the sage-kings emulated Heaven in their examination of a government through "elevating the worthy" and "employing the capable." ${ }^{2 I}$ And the chapter concludes with the desperate question:

Why do they [the current rulers] not examine how "elevating the worthy" is the foundation of government? This was the good behavior of the sages. ${ }^{22}$

Aside from the almost annoying repetition of the title's expression, shang xian is also called a "basis for government" (zheng zhi ben 政之本), a type of "behavior" (xing 行), “my/our doctrine" (wu yan 吾言), and, in the following chapter, a "theory" or “explanation” (shuo 說) (IO: I6/2). Whoever reads this triplet, even with its titles temporarily removed, cannot fail to guess that the content-title must be "Shang xian," perhaps joined by "Shi neng” 使能 (employing the capable).

\section{A Relatively Good Match between Core Chapters and Their Titles}

Four triplets, two of which have not been completely transmitted, almost never contain the formulation of their title in the chapter. As Table 3 shows, this is the case for "Fei ming" (chs. 35, 36, 37), "Fei yue" (ch. 32), "Fei gong" (chs. I7, I8, I9), and "Ming gui" (ch. 3I). ${ }^{23}$ It is nevertheless possible that the earliest authors knew the titles before starting their diatribe against ( $f e i$ 非), respectively, fatalism (ming 命), music (yue 樂), aggression (gong 攻) - hence the expressions of the titles - and against the denial of ghosts (wu gui 無鬼).

I9 何以知尚賢之為政本也? 曰自貴且智者, 為政乎愚且賤者, 則治; 自患賤者, 為政乎貴 且智者, 則亂。是以知尚賢之為政本也. 9:10/I 8-I9.

20 言聖之不失以尚賢使能為政也。故古者聖王唯能審以尚賢使能為政. 9:I 2/II.

${ }^{2 I}$ 故古聖王以審以尚賢使能為政, 而取法於天. 9:I $2 / \mathrm{I} 7$.

22 故 [replaced by 胡] 不察尚賢為政之本也。此聖人之厚行也. 9:I3/I 8-I9.

${ }^{23}$ In this chapter the matter is somewhat complicated by the ambiguity of the title. The expression ming gui can also be translated as an adjective-noun construction ("enlightened ghosts" or "percipient ghosts") but in ch. 3I, it occurs more often as a verb-object construction "gaining/giving insight into (the existence of) ghosts." In the Dialogue Chapters, however, the former meaning seems to dominate in discussions about the ming (percipience, insight) of the gui. See Johnston 20I0, pp. lvii-lxi; Knoblock - Riegel 20I3, p. 30. 
TABLE 3

OCCURRENCE OF THE TITLE'S EXPRESSION IN THE TEXT OF

FOUR TRIPLETS WITH A RELATIVELY GOOD MATCH BETWEEN

THEIR CONTENT AND TITLES IN THE DAOZANG EDITION

\begin{tabular}{lccc}
\hline & 上 & 中 & 下 \\
\hline 非命 & $\circ$ & $\circ$ & $\circ$ \\
非樂 & $\mathrm{I}$ & III & III \\
非攻 & $\circ$ & $\circ$ & $\mathrm{I}$ \\
明鬼 & $\mathrm{C}$ & $\mathrm{I} /$ & $\circ$ \\
\hline
\end{tabular}

In "Fei yue" Mozi is said to attack the behavior of the elite by repeating ad nauseam that "making music is wrong” (為樂非也: $32: 55 / 25 \mathrm{ff}$, six times). The "Fei gong" triplet concludes by insisting on the importance of Mozi's "argument against aggression” (非攻之為說: I9:3 5/28). More interestingly, the two other triplets abundantly refer to fixed formulations for views - "there is fate" (you ming 有命) and "there are no ghosts" (wu gui 無鬼) - that they firmly condemn. The most elaborate case is Mozi's attack of fatalism, where you ming is more than any other expression in the whole book treated as a fixed formulation: said to be defended and taught by believers, and advocated as well as condemned since antiquity. It is interesting to see how in these chapters, fixed formulations attributed to the opposition dominate the discourse. In "Ming gui" for instance,

those who nowadays hold on to "there are no ghosts" say: "Ghosts and spirits definitely do not exist." Morning and evening they preach this doctrine to the world, confusing the masses in the world, and making them all uncertain about whether or not ghosts and spirits exist, thereby throwing the world into chaos. ${ }^{24}$

I suspect that before the emergence of some fixed Mohist ideas, there existed no frightening multitude of thinkers stubbornly advocating and teaching these oppositional views, or at least not under the labels that the Mozi ascribes to them here: you ming and wu gui. Those expressions belonged initially, I believe, to the Mohist discourse. Perhaps the belief in fate was assumed of held by some individual masters or groups, and the Mohists tried to get a grip on them by converting these supposedly held views into fixed formulations. Or perhaps the causes of the Mohist irritation were not teachings or views, but longstanding attitudes and habits of the elite, which the Mohists now converted into convictions of a group of people in order to make them more manageable in debate. Philosophy in early China may have been created or at least shaped by this maneuver of converting implicit beliefs and age-old attitudes into more graspable opinions. ${ }^{25}$

The wording of these chapters furthermore suggests that the Mohists may have created fixed formulations for their opponents before identifying some of their

\footnotetext{
24 今執無鬼者曰: 「鬼神者, 固無有。」旦暮以為教誨乎天下, 疑天下之眾, 使天下之眾 皆疑惑乎鬼神有無之別。是以天下亂. 31:50/29-30.

${ }_{25}$ This point further elaborates on Dan Robins' attempt to trace the increasing attention to rivals in the Mohist Core Chapters. See Robins 2008, pp. 396-399.
} 
own. A "reject X" formulation may, at least initially, have functioned better as title than as slogan for actively promoting a policy. But we know from some other sources and from one passage in the "Lu wen" 魯問 chapter discussed below that, at least somewhat later, Mozi was sometimes associated more or less literally, with "fei X" mottos. This shows that the fei formulations also came to actively represent Mohist thought, at least in the eyes of some authors. ${ }^{26}$

\section{A Relatively Poor Match between Core Chapters and Their Titles}

In the last set of four triplets (Table 4), the connection between content and titles is less straightforward: again in diminishing order "Tian zhi" (chs. 26, 27, 28), "Jie yong" (chs. 20, 2I), "Jie zang" (ch. 25), and "Jian ai" (chs. I4, I 5, I6). Not only is the exact formulation of the title remarkably absent from the chapters as in the previous category, ${ }^{27}$ here is also some divergence in content. Not knowing the current titles beforehand, very few readers would correctly guess them exclusively on the basis of the chapters' content.

TABLE 4

OCCURRENCE OF THE TITLE'S EXPRESSION IN THE TEXT OF FOUR TRIPLETS WITH A RELATIVELY POOR MATCH BETWEEN THEIR CONTENT AND TITLES IN THE DAOZANG EDITION

\begin{tabular}{llll}
\hline & 上 & 中 & 下 \\
\hline 天志 & $\mathrm{I}$ & $\circ$ & $\mathrm{I}$ [+3天之] [3天之志] \\
節用 & $\circ$ & $\mathrm{I}$ & $/ / /$ \\
節葬 & $/ / /$ & $/ / /$ & $\circ$ (I 節喪) \\
兼愛 & $\circ$ & $\circ$ & I \\
\hline
\end{tabular}

This category is headed by a dubious case because of the possible variants (according to some Qing scholars) in "Tian zhi, xia." 28 The "Jie yong" triplet is a rejection of wastefulness rather than a plea for moderation. On the basis of its content, it would have been more comfortable in the list of titles headed by fei 非, for instance

26 This would account for the three "Fei X" chapters in this category. For fei yue 非樂, see e.g. Zhuangzi, “Tianxia,” Huainanzi 淮南子, “Shuoshanxun” 說山訓 (Mountain of Persuasions), and Xunzi, "Fuguo" 富國 (Enriching the State); for fei ming 非命 see e.g. Huainanzi, "Fanlunxun" 氾 論訓 (Boundless Discourses), and Hanshu, "Yiwenzhi”; for fei gong 非攻 see Lüshi chunqiu, I 8/ 7.3 and the expression fei dou 非鬥 in Zhuangzi, "Tianxia" and Xunzi, "Fuguo."

27 Moreover, the only occurrence of the expression jie yong in the triplet is sometimes emended into qi yong 器用, “tools and utensils.” See e.g. Knoblock - Riegel 2013, p. I97. This emendation is not always made. See e.g. Sun Yirang 20II, p. I6I; Mei I980, pp. 240-24I; Johnston 20I0, pp. 204-205.

${ }_{28}$ This triplet might also fit in the previous group. Sun Yirang follows Bi Yuan's emendation of tian zhi 天之 into tian zhi 天志. (Sun Yirang 20I I, p. 2I I, p. 2I7). If we accept the three occurrences of, respectively, tian zhi 天之 and tian zhi zhi 天之志 as close variants of tian zhi 天志, then the expression occurs seven times in ch. 28 , which would create a contrast with chs. 26 and 27. Watanabe Takashi and Nicolas Standaert argue that "Tian zhi, xia" is chronologically the second chapter of the three. See Watanabe I977, pp. I5-I6; Standaert 2013, pp. 264-269. 
"Fei fei" 非費 (against wastefulness). ${ }^{29}$ The title of the sole remaining "Jie zang" chapter (ch. 25) cannot easily be guessed either: the authors systematically condemn those who "hold on to" hou zang 厚葬 (bury elaborately) and jiu sang 久喪 (mourn long), which they explicitly treat as a doctrine opposed to their own: “the doctrines of these two masters" (二子者言: 25:38/29). This is one of the chapters that, like those in the previous category, converts others into more manageable opponents. ${ }^{30}$

The most striking divergence between content and title occurs in the "Jian ai" triplet (chs. I4, I 5, I6). As I have argued elsewhere (Defoort 2013), it is possible that Mohism started out with a less controversial plea to ai ren 愛人 (care for others) in the oldest "Jian ai" chapter, which gradually evolved toward the more demanding ideal of "care for all" or "inclusive care" in the somewhat later "Will of Heaven" triplet, where the expression jian ai 兼愛 regularly occurs in what might have become a "fixed formulation." ${ }^{\text {I }}$ As Yoshinaga Shinjirō has pointed out, "Jian ai, shang" (ca. 380 BCE) can be seen as a disciple's attempt to explain what his master meant when he insisted that "we must encourage people to "care for others"” (不可以不勸愛人: I4:24/22). ${ }^{32}$ The author's explanation is that instead of “caring for oneself” ( $z i$ ai 自愛) we should “care for each other" (xiang $a i$ 相愛), in and beyond relationships of traditional reciprocity (hence the first emergence of jian as adverb in the triplet). "Jian ai, zhong" (ca. 350 BCE) defends the idea against opponents of inclusiveness (jian) tout court and insists on caring for the weak, the poor, the vulgar, and the simple of mind. This continues in "Jian ai, xia" (ca. 300 BCE), where the expression jian ai appears once and people are urged to feed the hungry, clothe the cold, support the sick, and bury the dead.

Considering our relative lack of certainty concerning the Mozi's original shape and structure, and the possible complexity of its creation, the conclusions of this simple test with titles can only be tentative. My claim is not that some of the titles are misfits or badly chosen: even those of the last category fit their chapters relatively well, especially if we assume that at one point in time there existed a fixed set of Ten Core Ideas that functioned for at least some Mohist authors or editors as a basic frame. But the comparison of the titles with the content does lead to some insights: First, it calls attention to the recurrent oppositional fixed formulations that were probably invented by Mohists to identify a group of opponents in order to defy them in debate. This does not necessarily mean that the authors of the "Fei X" chapters initiated reflection on topics that no other master had ever thought about, such as fate, ghost, and the luxury of burials. A second insight is that the ten members of the well-known set may have had a very different history, and that they may not have been conceived together at the outset of Mohism as parts of one coherent theory. The "Fei X" titles, for instance, perhaps only became fixed formulations at a relatively

29 Or $q u$ fei 去費. In ch. 20, fei 費 is condemned four times (twice as 去費), in ch. 2I three times. Moreover, as Jeffrey Riegel points out, ch. 20 "appears less concerned with frugality per se than with the steps that states must take in order to increase their populations" (Knoblock Riegel 2013, p. I92).

30 Lunheng 論衡, “Baozang” 薄葬 (Simple Burials) claims that "the generation values thick burials” (世尚厚葬), not the sages.

3I Watanabe I977, p. 4 dates them, respectively, to ca. $280,260,240$ BCE. The dating of the three "Jian ai" chapters below is also from ibid.

32 Yoshinaga I999, p. 3 I. 
late stage and therefore do not occur as such in the text, except in one long string of mottos discussed below.

\section{Attribution of One Single Core IdeA}

Following the titles' expressions and the oppositional argumentative mechanism identified in the "Fei X" chapters, we move to the identification of singular fixed formulations. This relies more on signs in their textual context, namely indications that one policy, conviction, doctrine or teaching was repeatedly singled out for advocacy, promotion, defense, challenge, or rejection. I distinguish between two types of single fixed formulations: those attributed to opponents, and those explicitly endorsed by the Mohist authors.

\section{Single Fixed Formulations Attributed to Opponents}

In his rejection of fatalism, master Mozi is quoted as criticizing those who "hold on to "there is fate"” (zhi you ming 執有命), an expression that occurs no less than twelve times in the first "Fei ming" chapter. "The statements of those who hold on to "there is fate”" (執有命者之言: 35:58/I 5 ) are a “major harm in the world" (天下之厚害: 36:6I/24), since they even "teach it to the stupid and simple crowd" (以教眾愚樸之人矣: 36:6I/I 5). Therefore Mozi insists that these doctrines "must be urgently condemned" (不可不疾非: 36:6I/24). The “Fei ming" triplet even retrospectively associates historical figures with the two opposite camps: the vicious last ruler of the Xia dynasty "held onto 'there is fate"” (執有命也: 36:6I/I7-I 8), while the exemplary founder of the Shang dynasty "condemned it" (非之: 36:6I/I 8). And many authoritative quotes from ancient sources are said to support Mozi's conviction. Unfortunately, not all have been preserved, but thanks to the wealth of today's archaeological discoveries, we can perhaps check the author's bold claim that "all the bamboo documents that consist of more than ten strips agree that it [fate] does not exist" (從十簡之篇以尚皆無之: $37: 63 / 3-4) .{ }^{33}$

The expression you ming 有命 (there is fate) occurs abundantly in the three "Fei ming" chapters - respectively I4, I I and 6 times - while the expression of the title, fei ming 非命 (against fate), is absent (see Table I). The formulation "there is fate" functions here as a fixed label invented by Mohists for a group of people who in their eyes “hold on" ( $z h i$ 執) to it, “teach” (jiao 教) or “claim” (wei 謂) it, and must be “condemned" ( $f e i$ 非) for it - hence the title of the triplet. Even though the Mohists firmly oppose the belief in fate, the expression you ming itself is not meant to be insulting nor denigrating, but to objectively label the opponents' view. However, to my knowledge, no group of people felt the urge to identify with this motto and use it in their defence of fatalism or the acceptance of fate. Other fixed expressions

33 To support his anti-fatalism reading, he even provides his own commentary on the use of the term jiao 矯 ("pretend") in an ancient quote from a not transmitted source. The Announcements of Zhong Hui says: "I heard that a man of Xia, pretending to be following a fate decreed by Heaven, issued orders to his people [...]" That person [Jie,] by declaring that existed what did not exist, was accordingly said to be "pretending." If he had declared that existed what actually did exist, how could he have been said to be “pretending”? 仲虺之告曰: 我聞有夏人矯天命布命于下 [...]。彼 用無為有, 故謂矯。若有而謂有, 夫豈為矯哉! 37:62/29-30. See also Knoblock - Riegel 2013, pp. 305-306. 
"held on to" by opponents in the Mozi are $w u$ gui 無鬼 (there are no ghosts) ${ }^{34}$ and the paired expressions bou zang 厚葬 (bury elaborately) and jiu sang 久喪 (mourn long). ${ }^{35}$ They are all attributed to opponents and occur very often in the Mozi chapters as opposed to the expressions of their own titles. This suggests that the earliest authors of these triplets were more active in creating formulations to get a grasp on their perceived opponents than in creating their own labels.

\section{Single Fixed Formulation of a Mohist Thesis}

Aside from the two triplets that advocate the policies of their own titles, "Shang xian" and "Shang tong," the explicit promotion of a single core dogma in the form of a fixed formulation is remarkably absent in the Mozi, at least if we search exclusively for the ten theses (see Table I). The one exception is jian ai, especially in some Dialogue Chapters. No other of the ten theses is being singled out as a fixed label for Mohist ideas throughout the book.

The authors of the Dialogue Chapter "Geng zhu” 耕柱 were aware that Mozi stood for "care for all" or "universal love" and that others rejected it. The expression is not preceded by a verb indicating advocacy; perhaps the Mohist authors only claim that their rivals "hold on to" ( $z h i$ 執) specific views. The occasional occurrence of jian ai in the Mozi (see Table I) as well as its contrast with opposite views in the Dialogues both mark it as a fixed label of Mozi's thought.

For instance, in one short dialogue, a critic of Mozi's ideals, Wumazi 巫馬子, summarizes the crucial difference in one line: "I differ from you master: I am not able to "care for all'." 36

He goes on to explain how the nearness of family is morally relevant for him. Mozi first politely listens to the argument and then defends his own support of jian ai, implicitly accepting Wumazi's identification of this thought with this formulation. In the same chapter, Wumazi attacks the idea of jian ai as follows:

You care for everyone in the world but cannot quite be said to benefit them; I do not care for everyone in the world but cannot quite be said to harm them. Since neither of us has had any effect, why do you consider yourself alone right and me wrong? ${ }^{37}$

The critic challenges Mozi's judgment of others in terms of "right" and "wrong" on the basis of the acceptance of jian ai, a challenge that Mozi again accepts when formulating his defense. It is perhaps not surprising that such an explicit treatment of jian ai as representative of Mohist thought occurs in a Dialogue Chapter, a part of the book where Mozi is consistently presented as a teacher, with opponents, followers and guests. The treatment of jian ai is less fixed and singled out in "Tian zhi, xia," where it is used several times to spell out Mozi's views. And in the last

\footnotetext{
${ }^{34}$ It occurs eight times in ch. 3 I, "Ming gui" and twice in ch. 48 . It usually occurs in the expression "Those who hold on to “there are no ghosts' say" 執無鬼者曰.

35 The "doctrines" of bou zang and jiu sang both occur I9 times in ch. 25 "Jie zang" and sometimes in the rest of the Mozi, usually together as a pair of two fixed formulations. The expressions also occur in other early sources such as the Lunyu, Xunzi, Zhuangzi, Hanfeizi, and Lunheng.

36 我與子異, 我不能兼愛. 46:102/24.

37 子兼愛天下, 未云利也; 我不愛天下, 未云賊也。功皆未至, 子何獨自是而非我哉. 46: IOO/2O-2I.
} 
"Jian ai" chapter, where the expression jian ai probably occurs for the very first time, it may not yet have been fixed.

Perhaps other expressions, more or less related to the Ten Core Ideas, were treated as fixed formulations before the "Lu wen" string and the Core Chapter titles were created and gained a certain status. If we consider these two together as testimonies of one historically contingent, now current, view of Mozi's thought, we could perhaps identify other formulations that, with a different twist of history, might have ended up in a set of Mohist core ideas. Because of their recurrence in the Mozi, good candidates might be ai ren 愛人 (care for others) and li ren 利人 (benefit others), often forming a pair. Closely related is the ideal of "inclusiveness" (jian 兼), which is singled out in the two last "Jian ai" chapters as a value systematically attacked by the opponents, "who hear all about inclusiveness and condemn it” (皆聞兼而非之者: I6:29/I5). Even though consisting of only one character, jian may have functioned as an independent concept for some time, perhaps before jian ai replaced it. ${ }^{3}$ Yet another candidate is shi neng 使/事能 (employ the capable), closely paralleled with the core policy of shang xian (elevate the worthy). ${ }^{39} \mathrm{~A}$ last expression to be considered is wei $y i$ 為義 (do what is right), a formulation that figures prominently in the Dialogue Chapters. ${ }^{4 \circ}$ It is sometimes exclusively associated with Mozi, ${ }^{4 \mathrm{I}}$ but also attributed to other "gentlemen who work at doing what is right” (為義之君子) but who lack insight in what is really right, at least in the eyes of the self-proclaimed Mohist "knights of the right" ( $y i$ sh $i$ 義士: 47:106/ 4-7). ${ }^{42}$ Perhaps some of these expressions (e.g. ai ren, wei $y i$ ) were not exclusively Mohist enough or they functioned as a broader slogan referring to the overall Mohist mission rather than to one idea. ${ }^{43}$

\section{Strings of Fixed Formulations in the Mozi}

As Table I shows, fixed formulations of the Ten Core Ideas do not occur particularly often in the Mozi, but when they do pop up, it is mostly in strings that represent master Mo's views. While not explicitly preceded by verbs such as "advocate" or

38 Defoort 2013, p. 50.

39 The expression fei $r u$ 非儒 (against the $r u$ ) is no good candidate, even though it is sometimes considered the eleventh core thesis. This expression is the title of two chapters (ch. 39 and the lost ch. 38 ) but does not occur in any string in the Mozi, nor as single label, except perhaps once in a dialogue: “非儒，何故稱於孔子也” (48:I09/I 5). Here the expression can be translated as “You condemn the $r u$ " (Li Shenglong I996, p. 445; Knoblock - Riegel 2013, p. 362) or as "You are not a Confucian [or ru]" (Johnston 2010, p. 69I).

$4 \circ$ Aside from the Dialogue Chapters 46 (“Geng zhu”), 47 (“Gui yi” 貴義), 48 (“Gongmeng”公 孟) and 49 ("Lu wen"), the expression wei yi is also the topic in one fragment in ch. 8, "Shang xian, shang" and occurs once in ch. 28, "Tian zhi, xia."

${ }^{4 \mathrm{I}}$ An old friend says to Mozi: "Nowadays no one in the world does what is right. Only you torture yourself to do what is right. You should stop with this.”今天下莫為義。子獨自苦而為 義。子不若已. 47:103/28-29.

$4^{2}$ This is perhaps also the reason why he disagreed with the rustic Wu Lü 吳慮 (a name sounding like 無慮 [“one who has no reflection”]), who claimed that doing the right thing was enough and that further preaching was pointless (義耳義耳, 焉用言之哉). Mozi responded that he, from his side, had reflected ( $l \ddot{u}$ 慮) upon the matter and concluded that explanations are of crucial importance (49: II3/25-29).

43 Knoblock - Riegel 2013, p. 325. 
"hold on to," they occur in contexts of political advice or debate; the string form itself seems to put them aside as identifiable formulations. There is, moreover, some repetition in their content. Aside from one long string of (nine or) ten fixed formulations which largely coincide with the titles of the Core Chapters, the Mozi contains seven shorter strings of two or three identifiable formulations that are more or less fixed. They are often locations of forgotten textual emendations.

\title{
One Long String
}

The one long string of (nine or) ten fixed formulations occurs in the Dialogue Chapter, “Lu wen": When Wei Yue 魏越 asks his master how the latter would advise the lords of the various states, Mozi answers in what sounds like a summary of his thought: depending on the situation of the state, he would bring up a specific policy:

\begin{abstract}
Whenever you enter a state, you must select a task and work on it. If the state is in disorder, expound to them "elevating the worthy" and "conforming upward"; if the state is impoverished, expound "moderate expenses" and "moderate burials"; if the state overindulges in musical entertainment, expound "against music" and "against fatalism"; if the state is dissolute and indecorous, expound "revering Heaven" and "serving ghosts"; if the state is devoted to aggression and intimidation, expound "inclusive care" and "against [military aggression." Therefore], I say: select a task and work on it. ${ }^{44}$
\end{abstract}

Since the late Qing dynasty - but, to my knowledge, never before - this short dialogue has increasingly functioned as representative of (early) Mohist thought. Around the same time scholars started noticing the titles of the Core Chapters and the close similarity with this fragment: ${ }^{45}$ minor differences are that the "will of Heaven" (tian $z h i$ 天志) is here labeled "revere Heaven" (zun tian 尊天) and "insight in (the existence of) ghosts" (ming gui 明鬼) is here “serving ghosts” (shi gui 事鬼). The other strings are much shorter and contain somewhat less fixed formulations, but they all consistently contain these two variants rather than the titles of the triplets. This helps to explain why in Table I the expressions of the title ming gui and tian $z h i$ do not occur in the book Mozi, except as titles of Core Chapters. Perhaps the exceptional length of this one string in "Lu wen" together with the fixation of its formulations attests to a late phase in the Mozi's formation. ${ }^{46}$

A seldom noticed (because considered philosophically irrelevant) textual detail of this long string is that its tenth policy, namely "Against aggressive warfare" ( $f e i$ gong), was partially absent from all extant editions preceding Sun Yirang's 孫詒

44 凡入國, 必擇務而從事焉。國家昏亂, 則語之尚賢尚同; 國家貧, 則語之節用節葬, 國 家說音湛湎, 則語之非樂非命; 國家淫辟無禮, 則語之尊天事鬼; 國家務奪侵凌, 則語之兼愛 非[攻。故] 日擇務而從事焉. 49:I I 4/7-IO.

45 The order of the ten policies does not exactly coincide with that of the Core Chapters, but the paired policies in "Lu wen" are all consecutive triplets.

${ }_{46}$ The currently dominant Mozi interpretation is based on this "Lu wen" string and on the Core Chapter titles. These two textual testimonies were probably connected in the creation of the book Mozi. Taeko Brooks dates the "Lu wen" chapter around 262 BCE (Brooks 20IO, p. II 5 ). 
讓 (I848-I908) Mozi jiangu 墨子閒詁 of the late I9th century. The text stopped with fei (非) and continued with yue (曰) without leaving any blank space. This corruption has been restored by Wang Niansun 王念孫 (I744-I 832) in his Dushu zazhi 讀書雜志 (Miscellaneous Reading Notes). ${ }^{47}$ He was first followed by Sun Yirang ${ }^{48}$ and then by the whole scholarly community. The emendation was so convincing that it has since then been overlooked and unmentioned by translators (Mei Yi-pao I980, pp. 502-503; Li Shenglong I996, p. 463; Tan - Sun 2009, p. 404; Johnston 20IO, pp. 7I4-7I 5; Knoblock - Riegel 20I3, p. 379). But the long lack of attention for this corruption, even by excellent Mozi scholars such as Bi Yuan 畢沅 (I730I797), Sun Xingyan 孙星衍 (I753-I8I8), the Siku quanshu 四庫全書 editors (in I778), Zhang Huiyan 張惠言 (I76I-I802), and Yu Yue 俞樾 (I82I-I907) shows that there was a time, not very long ago, that the fixed set of ten theses was not considered crucial in the presentation of Mohist thought. Their lack of interest in the Ten Core Ideas is confirmed by the prefaces written by these scholars for their Mozi editions. ${ }^{49}$ This fact may not alter our current philosophical interpretation of early Mohism, but for the history of thought it is a fascinating given.

\section{Short Strings}

Aside from this unique long string, there are other instances where various formulations appear together as mantras of Mohist convictions: they occur far and apart in the book, are much shorter, less fixed, resemble each other, and show more affinity with the long "Lu wen" string than with the Core Chapter titles. The possibly longest among them comes from another Dialogue Chapter, in which the $r u$ Gongmengzi 公孟子 asks why Confucius was not made Son of Heaven since he knew well the odes, documents, rituals, music, and the multitude of things. Mozi points out that other proficiencies are expected for one to be considered wise, namely:

You know, a wise person must revere Heaven and serve the ghosts, love others, and use moderation. A combination of these makes one wise. ${ }^{50}$

The context of this string is a debate between masters, where the opponent adopts the Mohist promotion of talented men in order to - unsuccessfully, of course challenge people's failure to value Confucius' worth. In his response, Mozi imposes as a prerequisite for deserving respect, his own ideology in the form of a set of identifiable formulations: we recognize the pair zun tian and shi gui

47 "The two characters gong and $g u$ were missing from the old edition. I added them now on the basis of the text above and the 'Fei gong' chapters." 舊本脫攻故二字。今據上文及非攻篇。補. See Wang Niansun 2004, p. 207.

$4^{8}$ See Sun Yirang 20I I, p. 475.

49 Bi Yuan's edition Mozi zhu 墨子注 of $\mathrm{I} 783$ does not correct the fragment but enthusiastically quotes the set of nine core ideas in his preface; Zhang Huiyan's preface of I 792 quotes eight out of the Ten Core Ideas; Yu Yue in his Zhu zi pingyi 諸子平議 (Balanced Deliberations on the Masters) of I 870 does not mention Wang Niansun's correction. See Defoort 2015, pp. 2I3-22I.

50 夫知者必尊天事鬼愛人用節。合焉為知矣. 48:107/27. 
from the "Lu wen" string quoted above. The expression ai ren 愛人 (care for others) naturally reminds us of the core idea "inclusive care" and is often interpreted as such; but the recurrence of ai ren in the book Mozi, especially in its short strings, indicates that this expression may have functioned as a more common formulation among the Mozi's earliest authors before it was specified as the now well-known fixed formulation jian ai. ${ }^{5 \mathrm{I}}$ And finally, the string may have contained a fourth formulation, namely "moderate expenses" (jie yong 節 用), if we follow the scholarly emendation. This is indeed what most translators do, again without mentioning the oldest extant version..$^{2}$ The emendation is not unfounded, but the original yong jie 用節 (use moderation) has its merits too: the formulation jie yong does not occur in any other short string - it actually hardly occurs in the whole book (see Table I); on the other hand, appreciation for people who have jie 節 (moderation) does occur in the Mozi too. ${ }^{53}$ The Qing emendation may have been inspired by the emerging expectation to identify the then discovered core theses in the Mozi.

A second and last short string fully quoted here occurs in ch. 4 "Fa yi" 法儀 (Standards), the only Opening Chapter that contains a fixed formulation, but also thanks to an emendation. The author claims that:

The sage-kings of the past - Yu, Tang, Wen, and Wu - included all the Hundred Clans of the world when leading them to revere Heaven and serve the ghosts. ${ }^{54}$

In the Daozang edition, this string consisted of only the two fixed expressions that occur in all strings, namely zun tian and shi gui. But in $\mathrm{I}_{783}$, Bi Yuan added the character $a i$ 愛 behind jian 兼, “on the basis of the meaning” ( $y i$ yi zeng 以意增) (Sun 2OI I, p. 23). Again this emendation does make sense, and it has again been followed by translators without leaving any trace (Mei I980, pp. 30-3 I; Johnston 2010, pp. 28-29; Knoblock - Riegel 20I3, pp. 59-60.). But the original text is also worthwhile preserving and shows the Mohist authors using fewer fixed formulations or perhaps less fixed formulations. ${ }^{55}$

This suspicion is confirmed by the five remaining short strings that are not quoted and discussed in full (Table 5).

${ }^{\text {I }}$ Ai ren occurs 48 times in the book Mozi, much more often than jian ai (see Table I) even in its own triplet.

${ }^{52}$ It was for the first time corrected in Bi Yuan's edition of $\mathrm{I}_{7} 8_{3}$, but he left no comment. Henceforth the emendation is followed and unmentioned. See, e.g. Sun Yirang 20II, p. 454; Mei Yi-pao I980, p. 466; Li Shenglong I996, p. 437; Tan - Sun 2009, p. 389; Johnston 2010, p. 68I; Knoblock - Riegel 2013, p. 356.

53 See "Fei ming, shang." As a result of the statutes and edicts of the sage-kings of antiquity, the people were well ordered: "Their periods of repose and activity were measured, their comings and goings were moderated, men and women maintained the separation” (坐處有度, 出入有節, 男女 有辨. $35: 59 / \mathrm{I} 6$ ).

54 昔之聖王禹湯文武兼天下之百姓, 率以尊天事鬼. 4:5/I.

55 Without adding ai, the Mozi's verbal use of jian grammatically resembles Mencius' claim that "the Duke of Zhou included the Yi and Di, chased the ferocious animals, and the people were at ease” (周公兼夷狄, 驅猛獸而百姓寧. Mencius ${ }_{3} \mathrm{~B} 9$ ). As a support for Bi Yuan's emendation, it deserves notice that the Qunshu zhiyao 群書治要 (from 63I) quotes this line with the expression jian ai. 
TABLE 5

THE SEVEN SHORT STRINGS OF LESS FIXED FORMULATIONS IN THE MOZI (BASED ON THE DAOZANG EDITION)

\begin{tabular}{|c|c|c|c|}
\hline Chapter & $\begin{array}{l}\text { ISC } \\
\text { concordance }\end{array}$ & $\begin{array}{l}\text { Fixed } \\
\text { formulations }\end{array}$ & Comments \\
\hline $\begin{array}{l}\text { ch. 4, "Fa yi" } \\
\text { (discussed above) }\end{array}$ & $4: 5 / \mathrm{I}$ & $\begin{array}{l}\text { 兼[愛]+ 尊天 + } \\
\text { 事鬼 }\end{array}$ & $\begin{array}{l}\text { emendation adding 愛; surrounded by } \\
\text { various 愛人 }+ \text { 利人, which might at some } \\
\text { point have been fixed }\end{array}$ \\
\hline $\begin{array}{l}\text { ch. 9, "Shang xian, } \\
\text { zhong" }\end{array}$ & $9: \mathrm{I} 2 / 2 \mathrm{I}$ & $\begin{array}{l}\text { 兼而愛 + 尚尊天 } \\
\text { +事鬼 }\end{array}$ & $\begin{array}{l}\text { 兼而愛 and 尚尊天 are not fixed; 兼而愛 is } \\
\text { followed by 從而利 }\end{array}$ \\
\hline $\begin{array}{l}\text { ch. 26, "Tian zhi, } \\
\text { shang" }\end{array}$ & $26: 43 /$ I I & $\begin{array}{l}\text { 尊天 + 事鬼神 + } \\
\text { 愛人 }\end{array}$ & 事鬼神 and 愛人 are not fixed \\
\hline $\begin{array}{l}\text { ch. } 35 \text {, "Fei ming, } \\
\text { shang" }\end{array}$ & $35: 59 / 9$ & $\begin{array}{l}\text { 兼相愛 +上尊天 } \\
+ \text { 事鬼 }\end{array}$ & $\begin{array}{l}\text { 兼相愛 is followed here (and elsewhere) by } \\
\text { 交相利, which makes it a longer slogan }\end{array}$ \\
\hline $\begin{array}{l}\text { ch. } 48 \text {, "Gongmeng" } \\
\text { (discussed above) }\end{array}$ & $48: 107 / 27$ & $\begin{array}{l}\text { 尊天+事鬼 + 愛 } \\
\text { 人 [ 節用] }\end{array}$ & 用節 is emended into 節用 \\
\hline ch. 48 , "Gongmeng" & $48: \operatorname{III} / 7$ & 尊天 + 事鬼 + 愛 & 愛人 is not very fixed \\
\hline ch. 49, "Lu wen" & $49:$ I I I $/ 23$ & 尊天 + 事鬼 + 愛 & $\begin{array}{l}\text { 愛 is not fixed but retained because of its } \\
\text { recurrence in the strings }\end{array}$ \\
\hline
\end{tabular}

The information not only underscores the difficult nature of the endeavor to identify fixed formulations, but also provides us with some extra information. As for the difficulties, the remarks in the column to the right indicate some later emendations and show that many formulations, even though identifiable with one of the Ten Core Ideas, are relatively unfixed compared to the ten Core Chapter titles and to the "Lu wen" string. Strictly speaking not one formulation coincides exactly with the Core Chapter titles, at least if we consider the un-emended text. Some formulations moreover seem to have functioned as part of a longer Mohist slogan (e.g. 兼相愛交 相利), while other expressions (e.g. ai ren 愛人, li ren 利人) might at some point have been relatively fixed.

But the seven short strings also yield some novel information. They are remarkably short, containing two to three formulations, all relating to the same core ideas: concerning Heaven, the ghosts, and care for others. The other Mohist theses are not once included - that is if we do not include the emendation of yong jie 用節. This opens up a host of questions and hypotheses: Are we to conclude that the authors knew well their master's philosophy of ten theses but were not (yet) fully in the habit of using fixed formulations? Was there a reason why only two or three core ideas were being promoted in strings? Does the extant Mozi represent one (religious) faction of Mohism? Or do the short strings (with only Heaven, ghosts and care) attest to a gradual emergence and slow fixation of Mohist thought during the formation of the book?

\section{CONCLUSION}

It is not impossible that the philosophy promoted in the Mozi originated in the mind of one historical figure and consisted of Ten Core Ideas: there may have been a Mo 
Di in the Warring States period who preached ten clear doctrines, perhaps even using precisely the ten fixed formulations that dominate our current textbooks. But the fact that this particular portrayal of Mozi does not seem to have existed before the late I9th century has inspired an approach that does not presuppose it. It is equally possible, I believe, that some early authors of the Mozi were not aware of a complete set of ten central mottos. If the founder of Mohism had from the very outset expounded on a set of core ideas - with or without fixed formulations - it is strange that his fervent adherents only once explicitly expressed their support for this full string of ten, in a fragment that remained unnoticed by any master or scholar in Chinese history until the I9th century. My alternative portrayal is that early Mohist thought may have gradually come into being at the hands of various authors and editors, that the habit of arguing in terms of increasingly fixed formulations was a late Warring States phenomenon to which the Mozi's authors contributed, and that Master Mo was the person to whom all these ideas were attributed rather than their inventor.

Even though all this does not invalidate philosophical interpretations of early Mohism, scholars who are interested in what emerges when putting on hold some building blocks of the current portrayal of Mozi may want to follow an alternative thread focusing on the differences between the Ten Core Ideas, the fluidity of some formulations, the creation of oppositional mottos, and the textual emendations by Qing scholars. This research could continue in at least three directions. First, the study of fixed formulations is just one entrance into the masters' literature, showing one particular way in which philosophies were shaped in the late Zhou dynasty. While the Mozi contains the first testimony in Chinese history of a group of people identifying with some specifically labeled policies, it was less consistently than academic presentations of Mohism nowadays claim. For example, the positive identification with fei $\mathrm{X}$ expressions does not yet exist in the relevant chapters, but only appears in the "Lu wen" string and the titles. Other pre-imperial or early imperial texts do not contain a very consistent presentation of the Mohist core doctrines either (Defoort 20I4). This article could therefore be supplemented with a detailed study of the fixed formulations attributed to Mohists in other sources, ${ }^{56}$ the later

${ }^{56}$ A very rough count of the most often (more or less fixed) formulations attributed to the Mohists in other sources are, in diminishing order (several quoted in this article):

(г) 兼愛: literally in Mencius 3B9, 7A26; Huainanzi, "Fanlunxun”; Hanshu 30; Zhuangzi, "Dao zhi" and “Tianxia" saying 泛愛兼利.

(2) 節用: Zhuangzi, “Tianxia”; Xunzi, “Fei shi’er zi” saying 上功用, 大儉約, “Fuguo,” also saying 尚儉; and Shiji, “Mengzi Xun qing liezhuan" and “Taishigong zixu," both adding qiang ben 彊 本 (strengthening the roots);

(3) 非樂: in Huainanzi, "Shuoshanxun"; Xunzi, "Fuguo," in "Yuelun" saying that Mozi 非之 "rejects it [music]"; Zhuangzi, "Tianxia."

（4）明鬼: in Huainanzi, “Fanlunxun” saying 右鬼; Hanshu, “Yiwenzhi” saying 右鬼; Lunheng, “Fuxu” saying 右鬼神, “Bao zang” saying 右鬼 and 事鬼.

(5) 非攻: in Lüshi chunqiu, I 8/7.3; Xunzi, "Fuguo" saying 非鬥; Zhuangzi, “Tianxia” saying 非鬥.

(6) 非命: in Huainanzi, "Fanlunxun"; Lunheng, "Mingyi" saying 無命; Hanshu, "Yiwenzhi"

(7) 節葬: in Lunheng, “Bao zang” 薄葬; Mencius 3 A 5 saying that Mo's burials (喪) “以薄為其道 也” (considered simple as the proper Way).

(8) 尚賢: in Huainanzi, "Fanlunxun”; Hanshu, "Yiwenzhi." 
history of each so-called Mohist core idea, and the ideas in the Mozi that are not expressed in fixed formulations. ${ }^{57}$

The second line of research concerns the importance and prevalence of oppositional expressions in the Mozi: it seems that some of the Mohist authors were more active in the creation of fixed formulations to pin down the ungraspable opponent with his despicable habits and beliefs, than to positively identify their own group with some fixed labels. It would be interesting to trace the history of these formulations - "there are no ghosts," "there is fate," "elaborate burials," and "long mourning" - and see how they were incorporated, neglected, rejected, or accepted by other masters.

The third suggestion is that methodologically putting assumptions on hold can lead to insights that do not necessarily answer existing questions. For instance, acceptance of the chapter titles as historical artefacts, even though we do not know when exactly to date them, creates a release from their strong influence on the reader. Likewise, the historicity of our current view of early Mohist thought has a liberating effect and calls attention to the expectations behind some textual emendations. Even though such an approach might somewhat undermine the solid story that we tell about the "founder of Mohism," it also offers tantalizing bits and pieces of various Mozi portrayals in different epochs, including our own.

\section{BIBLIOGRAPHY}

Ahern, Dennis. I976. "Is Mo Tzu a Utilitarian?" JCP 3 (I976) 2, pp. I85-I93.

Brandt, Richard. I989. "Comments on Chad Hansen's 'Language Utilitarianism'," JCP I6 (I989) 3-4, pp. 38I-385.

Brooks, A. Taeko. 20I0. "The Mician Ethical Chapters," Warring States Papers I (2010), pp. IOO-II 8 .

Csikszentmihalyi, Mark - Michael Nylan. 2003. "Constructing Lineages and Inventing Traditions through Exemplary Figures in Early China," TP 89 (2003) I-3, pp. 59-99.

Defoort, Carine. 2013. "Are the Three 'Jian ai' Chapters about Universal Love?," in: Defoort -Standaert 20I3a, pp. 35-67.

. 20I4. "Do the Ten Mohist Theses Represent Mozi's Thought? Reading the Masters with a Focus on Mottos," BOAS 77 (2014) 2, pp. 337-370.

- 2015. "The Modern Formation of Early Mohism: Sun Yirang's Exposing and Correcting the Mozi," TP IоI (2015) I-3, pp. 208-238.

Defoort, Carine - Nicolas Standaert. 20I3. "Introduction: Different Voices in the Mozi: Studies of an Evolving Text," in: $i d .2013$ a, pp. I-34.

- (eds.). 2013a. The Mozi as an Evolving Text: Different Voices in Early Chinese Thought. Leiden - Boston: Brill.

Guo, Chengzhi 郭成智. I990. “Mo Di guli kaobian yiwen” 墨翟故里考辯一文 (An Investigation into the Hometown of Mo Di), Zhongzhou xuekan 中州学刊 1990/5, pp. IOO-IO3.

. I 992. "Mozi guli Tengzhou shuo zhiyi 墨子故里滕州說質疑 (Doubting the Theory that Tengzhou was Mozi's Hometown)," Zhongzhou xuekan I992/5, pp. I36-138.

Hansen, Chad. I989. "Mo-Tzu: Language Utilitarianism," JCP I6 (I989) 3-4, pp. 355-380.

\footnotetext{
(9) 尚同: Hanshu, "Yiwenzhi."

(го) 天志: is never attributed to Mozi, even though it is a top favorite in the Mozi's own strings. Perhaps Heaven had become common good and was not specifically attributed to the Mohists.

57 A rough count of ideas defended or assumed in other chapters than their own triplet in the political-ethical chapters are (in diminishing order): 兼愛 (I7X), 非攻 and 明鬼 (I $3 \mathrm{X})$, 天志 (9x), 節 用 $(7 x)$, 尚賢 $(5 x)$, 節葬 $(4 x)$, 非樂 and 非命 $(2 x)$, 尚同 (Ix). There is not much evidence that the pairs of the "Lu wen" string all consistently support each other.
} 
Hanshu 漢書 (History of the Han Dynasty). 1992. Beijing: Zhonghua shuju.

Hashimoto Sumiya 桥元纯也. 2010. "Riben de Mozi gaiguan: Yi lunshuo leizhupian ('Shangxian' shang di ba-'Fei ming' xia di sanshiqi) de yanjiu wei zhongxin” 日本的《墨子》 概观一以论说类诸篇(《尚贤》上第八-《非命》下第三十七) 的研究为中心 (Japanese Views on Mozi: With a Focus on the Core Chapters), Renwen luncong 人文論叢 (20I0), pp. 259-279.

Johnston, Ian. 20I0. The Mozi: A Complete Translation. Hong Kong: Chinese University Press.

Knoblock, John - Jeffrey Riegel. 2013. Mozi: A Study and Translation of the Ethical and Political Writings. Berkeley: University of California Press.

Lau, D.C. (ed.). I995-. ICS Ancient Chinese Texts Concordance Series. Hong Kong: Commercial Press.

Li Shenglong 李生龍. I996. Xinyi Mozi du ben 新譯墨子讀本 (Newly Translated Reader of the Mozi). Taibei: Sanmin shuju.

Lin Qingyuan 林清源. 2004. Jian du boshu biaoti geshi yanjiu 簡牘帛書標題格式研究 (Title Patterns of Bamboo and Silk Documents). Taibei: Yiwen yinshuguan.

Maeder, Erik. I992. "Some Observations on the Composition of the 'Core Chapters' of the Mozi," EC I7 (I992), pp. 27-82.

Mei Yi-pao. I980. The Works of Motze. Taibei: Confucius Publications.

Robins, Dan. 2008. "The Moists and the Gentlemen of the World," JCP 35 (2008) 3, pp. $385-402$.

Schipper, Kristofer - Franciscus Verellen. 2004. The Taoist Canon: A Historical Companion to the Daozang. Chicago: Chicago University Press.

Schoenhals, Michael. I992. Doing Things with Words in Chinese Politics. Berkeley: Institute of East Asian Studies.

Shiji 史記 (Records of the Historian). I992. Beijing: Zhonghua shuju.

Soles, David. I 999. "Mo Tzu and the Foundations of Morality," JCP 26 (I999), I, pp. 37-48.

Standaert, Nicolas. 20I3. "Heaven as a Standard," in: Defoort-Standaert 20I 3a, pp. 237-269.

Sun Yirang 孫詒讓. 20I I. Mozi jiangu 墨子間詁 (Exposing and Correcting the Mozi). Beijing: Zhonghua shuju.

Tan Jiajian 谭家建 - Sun Zhongyuan 孙中原. 2009. Mozi jinzhu jinyi 墨子今注今译 (The Mozi with New Commentary and New Translation). Beijing: Shangwu yinshuguan.

Taylor, Rodney. 1979. "Religion and Utilitarianism: Mo Tzu on Spirits and Funerals," PEW 29 (I979) 3, pp. 337-346.

Vorenkamp, Dirk. I992. "Another Look at Utilitarianism in Mo-Tzu's Thought," JCP I9 (I992) 4, pp. 423-443.

Wang Niansun 王念孫. 2004. “Mozi zazhi” 墨子雜志 (Reading Notes on the Mozi), in: Ren Jiyu 任继愈 - Li Guangxing 李广星 (eds.), Mozi daquan 墨子大全 (Complete Mozi Collection). Beijing: Beijing tushuguan, vol. I4, pp. I-290.

Watanabe Takashi 渡邊卓. I977. “Mojia sixiang”墨家思想 (Mohist Thought). Translated by Hong Shunlong 洪順隆, in: Uno Seiichi 宇野精一 (ed.), Zhongguo sixiang zhi yanjiu 中國思 想之研究 (The Study of Chinese Thought). Taibei: Youshi wenhua, vol. 3, pp. I-88.

Yoshinaga Shinjirō 吉永慎二郎. I999. “Jian ai shi shenme: Jian ai gainian de xingcheng he fazhan” 兼爱是什么一兼爱概念的形成和发展 (What is Care for All: the Formation and Evolution of the Concept of jian ai), Ha'erbin shizhuan xuebao 哈尔滨师专学报 1999/4, pp. $3 \mathrm{I}-34$.

Zhang Zhihan 張知寒. I99I. “Zai tan Mozi liji yingdang zai jin zhi Tengzhou” 再谈墨子里籍 应当在今之滕州 (Revisiting the View that Mozi's Hometown Must Have Been in Current Tengzhou), Wen shi zhe 文史哲 1991/2, pp. 92-97.

Zheng Qiangsheng 鄭強勝. I 998. “Quanguo Mozi yantaohui zongshu” 全国墨子研讨会综述 (Summary of the National Mozi Conference), Zhongzhou xuekan I998/I, pp. I I8-II9. 


\section{Chinese Abstract}

\section{$\lceil$ 十論」的遞增成形：對《墨子》中基本命題的追溯}

由於我們對於《墨子》「十論」早期文本的歷史所知甚少，因此在詮釋這些文本的時 候，難免需要依賴於某些預設。在這些預設之下，墨翟的形象是一位哲學家、是墨學的創 始人，也是「十論」這套連貫思想體系的倡導者。這些預設或許沒錯，但我們卻可以在方 法論上暫時擱置它們，而從一種新穎的方法來閱讀《墨子》。這個方法更關注的是「十 論」彼此之間的差異、它們在《墨子》當中尚未固定的形式、以及代表這「十論」的那些 詞語(例如「非攻」與「節用」)在《墨子》文本中鮮少出現的現象。這個新的方法論帶出 了另一個也同樣合理的對於墨家思想的描繪。這個描繪勾勒出墨家思想如何隨著《墨子》

一書逐漸地在各個時期的作者與編者手中建構成形。

關鍵詞: 《墨子》、「十論」、早期中國文本、清代校訂

\section{Notes ON CONTRIBUTOR}

Carine Defoort is Professor of Sinology at the Katholieke Universiteit Leuven. She is the editor of Contemporary Chinese Thought (Routledge, Taylor \& Francis) and corresponding editor for Europe of China Review International (University of Hawai'i). Recent research topics are the legitimacy of Chinese philosophy, Mozi, Zhuangzi, the weighing metaphor, and paradoxes concerning benefit.

Correspondence to: Onderzoeksgroep Sinologie, Leuven, Blijde-Inkomststraat 2I - bus 33 I 8, 3000 Leuven, Belgium. Email: Carine.Defoort@arts.kuleuven.be 